\title{
TRADITIONAL AND FEODAL AGRICULTURAL ECOLOGY : LAND SYSTEM IN THE ISLAMIC KINGDOM OF MATARAM
}

\author{
Sugiyarto ${ }^{*}$, Agustinus Supriyono \\ Department History, Faculty of Humanities, Diponegoro University, Semarang - Indonesia
}

\begin{abstract}
This article discusses apanage land belonging to village heads, which is a legacy of the land system in the era of pre-colonial Surakarta and Yogyakarta kingdoms or what is termed as as Vorstenlanden. As the aim was to find out how the feudal and nobility system in Java, which in the colonial era was very vulnerable to intervention and politics of splitting or fighting. To answer this question, a study will be conducted on the history of the Islamic Mataram kingdom until the era of Surakarta and Yogyakarta, en focusing on analysis of the apanage and nobility systems. The method used is a historical method which consists of four steps, namely, heuristics (activities to search for and collect historical sources), textual criticism (testing and assessing the authenticity of historical sources both in form and content), interpretation (interpreting historical facts obtained through text criticism) and historiography, namely presenting research results in the form of articles.
\end{abstract}

Keywords: Landssystem, Feodalism, Java

\section{Introduction}

What is meant by the land system in this paper is, how are the lands exploited in a system of government in the era of pre-colonial kings. While what was meant by the era of pre-colonial kings was the era before the Dutch government representing the Dutch royal government in the archipelago (Indonesia), namely after the collapse of the VOC in 1799 and was replaced by the Dutch East Indies colonial government.

The system of government in that era was commonly referred to as feudalism, namely the system of government that placed the king as the highest authority, while the nobles of the royal family and the bureaucratic apparatus were subordinates of the king's who were used as instruments to rule the people. Thus the people are the ruled inhabitants of the kingdom. . Besides that, in the feoadalism of power it was attributed to the nobility and the bureaucratic apparatus in line with the division of royal land. This means that the nobility and the bureaucratic apparatus obtained land from the king as an official land (apanage or feodum),

${ }^{*}$ Corresponding author : sugiyarto.efibe@gmail.com 
whose extent depends on the degree of nobility and position in the structure of the royal bureaucracy. The high degree of nobility and position in the bureaucratic structure would also affect the extent of the land of office. Then the lands were handed over to the people (farmers) as those who were ordered to work on these lands.

The legacy of the feudal system that can still be observed in the present is the salaries of village heads (Lurah) and also some village equipment in the form of apanage land. This is an irony, because the village head's own position in rural areas is determined through a democratic village head election system (pilkades). However, this paper is not primarily going to discuss the village head (lurah), but about the land system in era of the pre-colonial kings. In principle the nobles and royal officials from the highest to the lowest earn income or gajih in the form of official land or apanage land. However, how the system works or is implemented in the field is the main discussion in this paper

\section{Method}

This research is a qualitative study using historical methods consisting of heuristics, criticism, interpretation, and historiography [1]. Heuristics was the process to find primary and secondary sources [2]. Primary sources were obtained from observations, government or individual archives, and activities photos. Secondary sources are taken from relevant writings such as books, journals, and other literature. Secondary sources can be obtained from libraries, personal collections, and internet. The available sources are then criticized and interpreted. The analysis results above are then linked and reconstructed into an article about Traditional And Feodal Agricultural Ecology: Land System In The Islamic Kingdom Of Mataram.

\section{Nobility, Division of Kingdom Territory and Bureaucracy}

In the days of pre-colonial feudal kings, nobility, territorial division and royal bureaucracy were closely related to the land system. This can be understood because in essence the understanding of feudalism is a system of government in which the distribution of power runs parallel to the distribution of land to the the brokrasi apparatus and nobles. Thus land is very important in the implementation of power

There are two criteria for determining one's position in the stratification of the traditional Mataram kingdom community. The first is that the status of someone's nobility is determined by the blood relations of someone with the holder of power, namely the king. The second is determined by the position or position of someone in the royal bureaucratic hierarchy. By having one of these criteria, a person is considered to belong to the elite in the stratification of the traditional kingdom of Mataram society. For the criteria mentioned first, it is only occupied by nobles, which are based on blood relations with the holders or owners of power, namely the king.

While for the second mentioned can be from nobles or non-nobles. This means that a person, although not a noble, can be appointed and occupy a certain stratification in the royal bureaucracy.

Based on this explanation it can be concluded that the closer a person's blood relationship with the king means that the status the person's nobility is higher. On the contrary, the farther away the blood relation is from the holder of power, means that the degree of nobility decreases. In general, the degree of nobility only decreased to the heirs of the king to the fourth degree or the most distant to the fifth degree 
Based on the rules made by the king of Mataram, Amangkurat, which was then completed by Paku Buwana X, there are five levels in the nobility hierarchy, namely [3]:

1. The sons of the king, included in the category of gusti.

2. The grandchildren of the king, are included in the group of bendara

3. The great-grandchildren of the king, belong to the group of abdi sentana

4. The grandchildren of the king's grandchildren(canggah), are included in the group of bendara sentana

5. The grandchildren of The great-grandchildren of the king, para wareng raja, are included in the group of kawula warga

Meanwhile according to Van den Berg, there were only four noble titles outside the king. The highest degree, namely the sons of the king, who have the title of Prince, second is the grandchildren of the king with the title Raden Mas (male) and Raden Ayu (female), third is the great-grandchildren of the king with the title Raden (male) and Raden Nganten (female), fourth or last is the canggah of the king with the title Mas (male) and Mas Nganten (female) [4].

Together with the king as the highest authority, the nobility group occupied the highest strata in the social stratification of traditional Javanese society in the era of the Islamic Mataram kingdom. The closer a person's blood relationship with the king, means also the higher the social status. This principle of descent as a determinant of status results in the social mobility of people who are not of royal descent. This is exacerbated by habits in traditional societies which tend to maintain established social status as a harmony [5]. Such a system of social status is commonly referred to as ascribing status, which is social status obtained based on descent or birth without looking at or distinguishing spiritual differences and abilities.

Regarding the division of territories, before decreasing as a result of the annexation of territory by the Dutch, especially during the reign of Sultan Agung as the third king who ruled Matara Islam from 1613-1645, the territory of the Mataram kingdom still covered all of Central and East Java and part of West Java [6]. During the reign of the successor the kings of Sultan Agung the territory of the Mataram kingdom gradually diminished as a result of annexation by the Dutch.

In the system of government of Mataram Islam, the kingdom's territory was divided into 4 parts. The first is the Kuthagara or Kutha Negara region, which is the core area of the Mataram kingdom. It was in Kuthagara that the palace was located which was at the same time the place of the king and his extended family, and high-ranking royal officials. Kuthagara was also the center or capital of the kingdom, and the place of the king and highranking royal officials controlled the government [7].

In the outside of Kutha Negara there is territory what is called Negara Agung, which is also still included as the core territory of the kingdom, and which lies around Kuthagara. In this area lies the apanage land or tanah lungguh (which will be discussed behind) of the court nobles and high-ranking royal officials who reside in Kutha Negara. The areas that belong to the territoty of Negara Agung are Mataram (about the same as the current Yogyakarta), Pajang (located in the Southwest of Surakarta), Sukowati (located in the northeast of Surakarta today), Begelen, Kedu, Bumi Gede or Siti Ageng (areas located in the northwest of Surakarta, added with the area to the southwest of Semarang with an approximate line between Ungaran and Kedung Jati [8].

The third is outside the territory of the Negara Agung, there is an area called the Manca Negara. In accordance with the position of its direction from the center of the kingdom, namely Kutha Negara, the Manca Negara region is divided into two areaa, namely Manca Negara Wetan (East) and Manca Kulon (West). Unlike the territory of the Negara Agung, there are no apanage land of the nobles and high-ranking royal officials. However, when the Surakarta kingdom was governed by Paku Buwana IV (1788-1820), there was apanage 
land located in the Manca Negara region. It was as a result of the succesion war in the Yogyakarta Sultanate, between King Hamengku Buwana (HB) II against his own son, Prince Adipati Anom,. who wanted to seize the throne from his father. Adipati Anom requested assistance from the British, while king H.B. II requested assistance from Paku Buwana IV. In the battle in 1812 between the two rival parties, H.B. II was captured by the British and the Yogyakarta court was successfully occupied. Finally Adipati Anom succeeded in becoming king to replace his father [9]. Meanwhile Paku Buwana IV who has helped the king of Yogyakarta H.B. II was demanded by Britain to pay war compensation and gave up the region of Kedu, Wisobo and Blora. The surrender was outlined through an agreement on 1 August 1812 [10], and for the submission, P.B. IV received compensation of 12,000 ringgit. Instead of apanage land of the high-ranking royal officials in Kedu who were taken over by the British, Sunan gave apanage land in Madiun and Kediri region [11]

During the reign of the king of Paku Buwana II in Mataram Kartasura who ruled from $1726-1749$, the territory of the entire country as a whole covered the following regional areas:

a. Western Manca negara consist of: Banjar, Banyumas and sand (Purwakerta), Ngayah, Kalibeber, Modern (East Banyumas), Roma (Karanganyar), Karangbolong, Warah, Tersana, Karencang, Lebalsiyu, Balapulang, Bobotsari, Kartanegara, Bentar and Dayaluhur.

b. Eastern Manca Negara consist of: Panaraga, Kediri, Madiun, Pacitan, Magetan, Caruban, Kaduwang, Pace, Kertasana, Sarengat dan Blitar, Jipang, Grobogan, Warung, Sela, Blora, Rawa, Kalangbret, Japan, Wirasaba (Majaagung), Barebeg dan Jagaraga.

Areas outside the Manca negara and which are located farthest from the center of the kingdom are what is called the Pasisiran (coast). region This area is also divided into two parts, namely Pasisiran Wetan (East), covering coastal areas from Demak to the west, and Pasisiran Kulon (West), namely the area from the Jepara region to the east. During the reign of Paku Buwana II, the western Pasisiran areas consisted of areas: Brebes, Bentar, Labaksiyu, Tegal, Pemalang, Batang, Kendal, Demak, and Kaliwungu. While the eastern coastal region consists of areas: Jepara, Kudus, Cengkal, Pati, Juwana, Rembang, Pajangkungan, Lasem, Tuban, Sedayu, Lamongan, Gresik, Surabaya, Pasuruhan, Bangil, Banyuwangi, Blambangan, and Madura [12]. The Pasisiran territory of the Mataram kingdom gradually became shrinking since the reign of Paku Buwana II as a result of annexation by the Dutch (VOC).

About the bureaucratic system referred to in this paper is a way to regulate the course of government. As the center and the highest authority, the position of the king is actually outside the bureaucracy. But the king is the owner of the bureaucratic apparatus called the prijajis. The bureaucratic apparatus serves as a tool to run the government and control its people as the governed group. The king's power is absolute, because there are no other institutions or powers that can control it [13]. In other words, the royal bureaucracy is a tool used to control and run the government. The king's responsibility is quite moral in that it is a channel of collective interest and a symbol of consensus in maintaining the stability of economic and political life. Regarding the position of such a king, then there is a strict separation between the king as a source of law and power with the bureaucratic apparatus as an executive institution that carries out government duties [14].

In the palace environment, the nobles had a higher status than the bureaucratic apparatus. Besides that, the king and the nobles had the right to inherit power. Meanwhile the bureaucratic apparatus is a means of government of the king in order to bridge and regulate the relationship between the king and his people. The position of the bureaucratic apparatus is also very dependent on the king, because their appointment and dismissal is the right and by the king. But from this aristocratic class, generally high-ranking royal officials were 
appointed by the king [15]. This means that nobles have a much greater chance to occupy the highest strata in the bureaucratic structure than ordinary people.

In the structure of the royal bureaucracy, "Patih" actually occupies the highest position, and this patih is the leader of all bureaucratic apparatus. The bureaucratic apparatus has the task of carrying out the orders or the will of the king. Besides occupying the highest strata in the bureaucratic structure of the Islamic Mataram kingdom, Patih also served as the king's deputy, the king's right hand, the head of the subordinate officials, namely the regents. Before 1755, there were Patih Lebet (inside) in Mataram Surakarta and Patih Jawi (Outside). Patih Lebet is a coordinator and at the same time as the leader of high officials under him whose job is to manage the government in the palace (kraton). However, after 1755 the position of Patih Lebet was abolished, so that all government affairs in the palace were carried out by Wedana Lebet (see behind), and one of them, the Wedana Lebet, being its leader [16].

Meanwhile Patih Luar is the coordinator and leader of the Wedana Jawi, who has the task of managing the government in the territory of theNegara Agung. The Patih Luar tasks include tax and recruitment of workers if needed by the king at any time. The tasks of the Patih Luar are among others in the field of tax collection and recruitment of workers if needed by the king at any time. Patih Luar is the most important official in the royal government, because all orders for all the officials below are coming from and through Patih. This is in accordance with custom in the palace of the Mataram Islamic kingdom, which gives the meaning of Patih as parintah (order) or government. The point is that Patih is the provider of orders based on wisesa (power) from the king as the highest Authority [17].

Under the position of Patih there was the position of Pangeran Adipati Anom, and his full title Pangeran is Adipati Anom Sudibya Raja Putra Narendra Mataram. He is the king's son borned from the Permaisuri (main wife) and has been designated as a candidate for successor to the king (Crown Prince). If at any time there is a emptiness in the position of the king (for example because the king dies) and has not been crowned or appointed a new successor, then the Crown Prince will directly carry out the functions or duties of the king until he is appointed as the new king [18]. In the affairs of the state, the Adipati Anom was ranked the third position (after the king and the patih), but in the palace environment he occupied the second place, namely after the king. Therefore there is a clear distinction between Kepatihan (the patih residence) and the Kadipaten or Astana Pangeran (the residence of the princes). Patih is the head of the royal employees (priyayi), while the Adipati Anom is the head of a noble or aristocratic environment.

The royal bureaucratic officials who were directly under the chief of patih were the wedana or nayaka. In accordance with their respective work areas, the post of wedana is divided into two groups, namely Wedana Lebet (inside) and Wedana Jawi (outside). Wedana Lebet has duties inside the palace and consists of 4 wedana namely Wedana Keparak Kiwa (left), Wedana Keparak Tengen (right), Wedana Gedhong Kiwa and Wedana Gedhong Tengen. Wedana Keparak Kiwa and Wedana Keparak Tengen have duties in the field of soldier, and each leads 1.000 soldiers

About Wedana Jawi, which usually has the title Tumenggung or Kyai Tumenggung, it has duties outside the palace, namely in the territory of the Negara Agung. In accordance with their respective work areas there are 8 Wedana Jawi positions, namely, Wedana Bumi, Wedana Bumija, Wedana Siti Agung Kiwa, Wedana Siti Agung Tengen, Wedana Sewu, Wedana Numbak Anyar, Wedana Penumping and Wedana Panekar [19]. Thus they are regional heads in their respective work areas. However in the palace they have special skills or tasks. For example, during the reign of Paku Buwana II, the titles and duties of the wedana in the palace are as follows [20]:

1. Wedana Keparak Kiwa, Raden Tumengung Ngurawan, is an expert in the field of soldier, Javanese and Arabic literature, various language experts as well as translator 
2. Wedana Keparak Tengen, Raden Tumenggung Natawijaya, has expertise in making weapons, training in war, training spies and so on

3. Wedana Gedhomg Kiwa, Kyai Tumenggung Tirtawiguna, served in the financial field (bendahara raja) and expert in making soldier clothes

4. Wedana Gedong Tengen, Kyai Tumengung Mangun Nagara, expert in the field of Javanese cooking and arts

5. Wedana Sewu, Kyai Tumenggung Hanggawangsa and Wedana Numbak Anyar, both of them have the task of providing compulsory labor for the kingdom, seeking and providing beautiful people and providing strong people to carry out hard work such as diving and so on

6. Wedana Bumi Kyai, Tumengung Natayuda, and Wedana Bumija, Kyai Tumenggung Mangkuyuda, both have expertise in agricultur

The Wedana usually have multipurpose assistens who are also their representatives namely Kliwon, Penewu, mantri, lurah, bekel and jajar. Before 1831, Kliwon's subordinates were divided into seven ranks in sequence from the highest, namely penewu, penatus, peneket, panalawe, panigangjung, panajung mand panakikil [21].

In the Manca Negara and Pasisiran regions, there is the Wedana Bupati office which becomes the head of the regents. They are the Wedana Bupati Manca Negara Timur, Wedana Bupati Manca Negara Barat the Wedana Regent of the East, the Wedana Bupati Pasisiran Barat dan Wedana Bupati Pasisiran Timur. Regents in both regions usually have the title Tumenggung or Raden Arya [22]. They are officials appointed by the king, mainly based on consideration of their loyalty, and not based on their abilities [23]. The task of the regents is to collect taxes (tribute) that must be paid at certain times, namely at the time of the ceremony "Grebeg", as proof of their respect and loyalty to the king. Besides that they also had to provide armies or soldiers to help the central government during the war [24].

\section{Land Exploitation}

In the Mataram kingdom of Islam, the economic activities were still largely carried out by means of exchange, tribute consisting of yields and labor. Although there are already financial institutions in the center of the kingdom, but they have not yet functioned as the main economic tools of the kingdom. For the king, wealth is a tool that is hoarded and sometimes used to buy support, so it has never been considered an efficiency tool in a royal economic organization [25].

Meanwhile in the concept of Javanese power, the king was the owner of the land with absolute power. The land was distributed to bureaucratic officials and nobles as apanage land, and then handed over to the people to be cultivated [26]. ${ }^{24}$ The crops from the lands that were worked by the people in the villages, tribute or other obligatory offerings were handed over by the village heads (petinggi or bekel) to their leaders, i.e. the Demang. The demang then handed over to their superiors, the Panji, who usually held the title Tumenggung. The head of the Panji is the Wedana who then to be responsible directly to Patih [27].

In order to be able to control the lands that were cultivated by the people in the countryside or villages, the king appointed special officers, namely what was called bekel, petinggi and so on, which also functioned as a tax collector. They are of course also given rewards or some kind of salary, which is part of the village's land products in their respective work area. For these bekel, the king gives tax-free land, which covers one-fifth of the rice fields in their respective working areas. Then half of the rest, which is equal to $2 / 5$, is the right of the cultivator or farmer who they enjoy at each harvest. The remaining two-fifths left, one fifth should be reduced for the regent as head of the region and 1/5 again became part of the district heads such as Demang and Ngabehi. Thus the king only has to get part $2 / 5 \times 100 \%-2 / 5 \mathrm{x}$ $40 \%=40 \%-16 \%=24 \%$ of all crop yields in a district. A tax-free land system with an area 
of $1 / 5$ part of all paddy fields in the bekel working area or petinggi ) is called the system of perlimaan [28].

The unitary system of land in Java in the era of pre-colonial Islamic Mataram was the "jung" which the literal meaning is feet, and which is approximately equal to $50 \mathrm{x} 50$ cengkal $=2,500$ square roede. One jung can still be divided into 5 bau (bau = arm). The definition of literal meaning og bau or arm is the arm of a worker like a farmer or cultivator, which is then also called the term karya, which means work assignment. One bau is approximately the same as 500 square inches. However, in the simple land administration of Java, tax-free land from bekel was never taken into account in determining the extent of village land. Therefore, in the official tax register, 1 junk is only calculated as 4 bau or karya [29]. This means that for the size of one jung it still has to add a portion of bekel for 1 bau, so that it becomes 5 bau.

Thus the origin of the meaning of bau or karya is related to the understanding of labor unity. Then, especially since Mataram was divided into two kingdoms namely Surakarta and Yogyakarta (1755), emerged the meaning of cacah which was the same as 1/4 bau (karya). However, this understanding of cacah refers to the unity of land within a family. The size of the unity of the land in this cacah also simultaneously shows a lot of Real tax money each year. In Dutch terms, such family tax is referred to as hoofdgelden, which is a tax-setting unit for the land owned by the king. Therefore, every unit of land that provides a living for one person and his family, is taxed one Real per year, which directly becomes part of the king. Thus the notion of land area in the cacah also relates to the definition of one family tax in Real

The bureaucratic officials did not receive compensation for their work and position, but instead they obtained land loan or apanage land. The land portion of the position or apanage of bureaucratic officials is as follows:

1. Wedana Lebet

2. Wedana Jawi

3. Wedana Bumija

4. Wedana Bumi

5. Wedana Siti Ageng Kiwa

6. Wedana Siti Ageng Tengen

7. Penewu

8. Penatus

9. Panalawe

10. Panigang Jung

11. Panajung

12. Panakikil

$$
\begin{aligned}
& : 5.000 \text { karya } \\
& : 5.000 \text { karya } \\
& : 6.000 \text { karya } \\
& : 6.000 \text { karya } \\
& : 10.000 \text { karya } \\
& : 10.000 \text { karya } \\
& : 1.000 \text { karya } \\
& : 100 \text { karya } \\
& : 25 \text { karya } \\
& : 12 \text { karya } \\
& : 4 \text { karya } \\
& : 2 \text { karya }
\end{aligned}
$$

The area of apanage land of the Wedana Jawi is varied, which depends on the size of the area which is their respective work area. This means that if the area of work is getting wider, then the apanage land that can be owned is also wider and vice versa.

Those who obtained the portion of land apanage from the king were not only officials of the royal bureaucracy, but also the nobles of the royal family who did not become bureaucratic officials. They obtained the land of apanage, and each of them was as follows

1. Grandmother of the king (Ratu Eyang)

2. Mother of the King (Queen Mother)

3. The wife of the king (Ratu Kencana)

4. Crown Prince (Prince Adipati Anom)

5. Prince or Pangeran (son of the king)
: 1.000 karya

: 1.000 karya

: 1.000 karya

: 8.000 karya

: 1.000 nkarya 
The size of the apanage land is actually an official of the royal bureaucracy shows the high and low level of the official in the structure of the royal bureaucracy, while for the nobles shows their high degree of nobility.

For officials of the royal bureaucracy, the land of Lungguh or Apanage cannot be inherited to the descendants. This means that the land can only be enjoyed as long as someone still has the status as an official of the royal bureaucracy. If it has stopped from his position for various reasons, the land will automatically return to its owner, the king, who will then be given back to his successor. However, the extent usually decreases as the degree of one's nobility decreases. In the Javanese nobility, the degree of nobility of a king declined to a fifth degree. Under that degree, the descendants of a king can be considered as ordinary people. Even since the shrinking of the territories of Yogyakarta and Surakarta kingdoms in 1812 and 1830 as a result of annexation by Britain and the Netherlands, the nobility can only be inherited to the third degree [30].

\section{Conclusion}

From all of the descriptions above it can be seen that high officials and royal aristocrats have the power and the right to collect land tax and labor, because they have their own territories with great autonomy. Thus they are financially independent (autonomous) by having funds and funding to meet their own needs. Such circumstances are understandable because the central government does not pay them, and instead they are given the right to tax and organize labor in their own interests. This inability of the central government to pay the royal officials is mainly due to the undeveloped nature of the agrarian economy and the organization central financial.

The independence of royal officials and nobles was a reflection of the Javanese feudal land system, especially in Central and East Java during the pre-colonial kingdeom. This is different from medieval Western feudalism, where the term "Feudal" originated. In Western Europe at that time, the apanage land of the nobles could be inherited (inherited) to their descendants. It is based on the principle of Western nobility which can indeed be inherited, even though the blood relations of the king are increasingly distant or if a nobleman does not occupy a certain position in the bureaucratic structure. Thus a Dutch nobleman, "Graaf" for example, even though he finally did not become a king, his grandchildren would still carry the same noble title, Graaf. On the contrary, the level or degree of nobility of a king's son in Java will be higher than that of the king's grandson, and the grandson of the king will be higher than the great-grandson of the king and so on. Such a decline in the degree of nobility in Java will also affect the extent or amount of apanage land obtained.

Such a system of nobility in Java subsequently resulted in frequent succession wars or power struggles in the kingdom (Mataram), because every noble tended to maintain or increase the degree of their nobility by trying as much as possible to become king or at least having blood relations as close as possible to the king. Without such an effort, his son, his descendants would eventually be able to degenerate into ordinary people. While the bureaucratic apparatus, from the highest level, namely the patih to the lowest, namely the lurah or bekel, were completely unable to inherit their land of apanage to their children or descendants. However, the high-ranking officials in general were nobles of the king's large family, while the lower bureaucratic officials only tended to fight for their positions to be replaced by their descendants.

Regarding the common people, "small people" or farmers, are those who work on the land. Therefore they only enjoy a small portion of the results of working on land or rice fields, namely $2 / 5$ parts. Such a thing certainly greatly influenced the work ethic of the Javanese 
people in the future, namely the lack of enthusiasm for hard work. From the present point of view it can understand, namely the lack of encouragement or hope to be able to enjoy the results of hard work fairly

\section{Acknowledgement}

The research is funded by DIPA Diponegoro University in 2020 budget year

\section{References}

1. Garraghan, Gilbert., A Guide to Historical Method (1947)

2. Herlina, Nina., Metode Sejarah (2008)

3. Kartodirdjo, A. Sartono., Struktur Sosial dari Masyarakat radisonal dan Kolonial (1969)

4. Anoniem, Tedhakan Pranatan Tuwin Serat Warni-Warni Tumrap Nagari Surakarta

5. Peacock, James., "The Tradisional Society and Consciousness in Java: The Durkheim Perspective", in Indonesia, No. 19, April 1975

6. Kartodordjo, A. Sartono (et al.)., Sejarah Nasional Indonesia jilid IV (1977)

7. Kartodordjo, A. Sartono (et al.)., Sejarah Nasional Indonesia jilid IV (1977)

8. Rouffaer, G.P., Vorstenlanden, Uitdrukkerij-Adatrechtbundel XXXIV, Seri D, No. 81, 1931

9. Sudaryo, Sastra., Serat Pradjandjian Pranatan Lan Undhang-Undhang

10. Sudaryo Sastra., Serat Pradjandjian Pranatan Lan Undhang-Undhang; G.P. Rouffaer, Vorstenlanden

11. Rouffaer, G.P., Vorstenlanden, Uitdrukkerij-Adatrechtbundel XXXIV, Seri D, No. 81 1931

12. Brandes, J., "Pustaka Radja Puwara. Register op de Prosa Omzetting van de Babad", in $V B G, 1900$

13. Moertono, Soemarsaid., State and Statecraft in Old Java. A Study of the Later Mataram Period (1968)

14. Soemardjan, Selo., Sociaal Changes in Yogyakarta (1962)

15. Peacock, James., "The Tradisional Society and Consciousness in Java: The Durkheim Perspective", in Indonesia, No. 19, April 1975

16. Rouffaer, G.P., Vorstenlanden, Uitdrukkerij-Adatrechtbundel XXXIV, Seri D, No. 81 1931

17. Serat Kabar Wulanan Narpowandowo (1941)

18. Veth, P.J., Java: Geograpisch, Etnologisch, Historisch. Deel IV (1912)

19. Rouffaer, G.P., Vorstenlanden, Uitdrukkerij-Adatrechtbundel XXXIV, Seri D, No. 81 1931

20. Anoniem. Sri Radya Laksono (1949)

21. Rouffaer, G.P., Vorstenlanden, Uitdrukkerij-Adatrechtbundel XXXIV, Seri D, No. 81 1931

22. Schrieke, B., "Indonesia Sociological Studies", Ruler and Realm in Early Java Part II (1959)

23. Soemardjan, Selo., Social Changes in Yogyakarta (1962)

24. Soekanto, Soerjono., Sosiologi Suatu Pengantar (1969)

25. Onghokham., "Pungutan Dalam Sejarah" in Kompas, 14 Juli 1963 
26. Rouffaer, G.P., Vorstenlanden, Uitdrukkerij-Adatrechtbundel XXXIV, Seri D, No. 81 (1931)

27. Schrieke, B. "Indonesia Sociological Studies" Ruler and Realm in Early Java Part II (1959)

28. Rouffaer, G.P., Vorstenlanden, Uitdrukkerij-Adatrechtbunde XXXIV, Seri D, No. 81, 1931

29. Rouffaer, G.P., Vorstenlanden, Uitdrukkerij-Adatrechtbunde XXXIV, Seri D, No. 81, 1931

30. Rouffaer, G.P., Vorstenlanden, Uitdrukkerij-Adatrechtbunde XXXIV, Seri D, No. 81, 1931 